Tersedia online di: http://ejournal-balitbang.kkp.go.id/index.php/bawal
e-mail:bawal.puslitbangkan@ @gmail.com
BAWAL wIDYA RISET PERIKANAN TANGKAP
Volume 10 Nomor 2 Agustus 2018
p-ISSN: 1907-8226
e-ISSN: 2502-6410
BAWALAL
Nomor Akreditasi Kementerian RISTEKDIKTI: 21/E/KPT/2018

\title{
ANALISIS DEGRADASI LINGKUNGAN PERAIRAN DAN KETERKAITANNYA DENGAN KEMATIAN MASSAL IKAN BUDIDAYA DI WADUK CIRATA, JAWA BARAT
}

\section{ENVIRONMENTAL DEGRADATION ANALYSIS AND ITS RELATIONSHIP TO MASS MORTALITY EVENT OF CULTURED FISH IN THE CIRATA RESERVOIR WEST JAVA}

\author{
Adriani Sri Nastiti*1, Sri Turni Hartati ${ }^{2}$ dan Budi Nugraha ${ }^{2}$ \\ ${ }^{1}$ Balai Riset Pemulihan Sumber Daya Ikan. Jl. Cilalawi No.1 Jatiluhur -Purwakarta, Indonesia \\ ${ }^{2}$ Pusat Riset Perikanan. Gedung BRSDMKP Jl. Pasir Putih Ancol Timur Jakarta Utara, Indonesia \\ Teregistrasi I tanggal: 05 Desember 2017; Diterima setelah perbaikan tanggal: 19 Mei 2018; \\ Disetujui terbit tanggal: 04 Juni 2018
}

\begin{abstract}
ABSTRAK
Waduk Cirata dimanfaatkan untuk budidaya ikan dengan sistem keramba jaring apung, dimana jumlah keramba saat ini sudah melebihi daya dukung yang menyebabkan kelebihan hara (eutrofikasi). Di Waduk Cirata setiap tahun terjadi kematian ikan hasil budidaya. Penelitian ini bertujuan untuk mengidentifikasi masalah kematian masal ikan di Waduk Cirata. Pengumpulan data dilakukan pada saat terjadi kematian massal ikan akhir September 2017, di Zona I (Sangkalin, Cipicung-Bandung Barat), Zona II (Cimanggu-Purwakarta), dan Zona III (Jatinengang, Patokbeusi-Cianjur) menggunakan metode observasi cepat in situ, wawancara dan studi pustaka. Parameter yang diamati meliputi: Suhu air / udara, Kedalaman perairan, Warna air, Kecerahan, Kekeruhan, TDS (0,046-0,172 mg/l), TSS (total suspended solid), DHL (0,1-0,3 mS/cm), Oksigen terlarut, ORP (-49 sampai 244 mv), bebas $\mathrm{CO}_{2}$, Alkalinitas, pH, Nitrat, Nitrit, Amonium, Fosfat, Sulfat, BOT (5,06-17,06 mg/l), dan Kronologi kematian massal ikan. Hasil penelitian menunjukkan bahwa, kadar Oksigen terlarut dibawah $4 \mathrm{mg} / \mathrm{l}$ dan ORP nilainya negatif sehingga perairan tidak mampu menguraikan akumulasi limbah sebesar 390.848 ton/tahun. Kondisi tersebut mengindikasikan bahwa perairan mengalami degradasi, Degradasi lingkungan perairan dipicu oleh fenomena umbalan menyebabkan kematian massal budidaya ikan sekitar 65 ton (Zona III), 25 ton (Zona II), dan 20 ton (Zona I).
\end{abstract}

Kata Kunci: Degradasi; lingkungan perairan; kematian massal ikan budidaya; waduk Cirata

\section{ABSTRACT}

The Cirata reservoir is used for fish culture by floating net cage system that currently has been exceeded to its carrying capacity that caused an over nutrient (eutrophication). Every year, mass mortality event occurred in Cirata Reservoir. This research aims to identify the causal of mass mortality event in the Cirata reservoir. This research conducted at the end of September 2017 in several locations: Zone II (Cimanggu-Purwakarta), Zone I (Sangkalin, Cipicung-West Bandung), and Zone III (Jatinengang, Patokbeusi-Cianjur). A rapid in situ observation, interview and literature review. Parameters that measured include Water/air temperature, Depth, Watercolour, Brightness, Turbidity, TDS (0,046-0,172 mg/l), TSS (total suspended solid), DHL (0,1-0,3 mS/cm), Dissolved Oxygen, ORP ((-49 to $244 \mathrm{mv}), \mathrm{CO}_{2}$, Alkalinity, $\mathrm{pH}$, Nitrate, Nitrite, Ammonium, Phosphate, Sulphate, BOT (5,06-17,06 mg/l), and the chronology of mass mortality. The results showed that the dissolved oxygen was less than $4 \mathrm{mg} / \mathrm{l}$ and negative ORP value that indicated incapability of environment to decompose the feed accumulation waste (about 390.848 tons/year). The degradation of waters environment triggered by upwelling phenomenon could cause mass mortality event on fish culture in three zones about 65 tons (Zone III), 25 tons (Zone II) and 20 tons (Zone I), respectively.

Keywords: Degradation; water environment; mass mortality event; Cirata reservoir 


\section{PENDAHULUAN}

Waduk Cirata yang terletak di daerah aliran sungai (DAS) Citarum, dibangun pada September 1987 dengan fungsi utama sebagai penghasil energi pembangkit listrik tenaga air (PLTA) untuk Pulau Jawa lokasinya di Provinsi Jawa Barat. Awalnya waduk ini memiliki luasan sekitar 6.200 hektar dengan rata-rata kedalaman air adalah 34,9 meter dan terletak pada ketinggian 225 meter dari permukaan laut (Soemarwoto et al., 1990). Selain digunakan untuk sumber pembangkit listrik, badan air waduk ini dimanfaatkan untuk kegiatan budidaya ikan dengan sistem keramba jaring apung (KJA). Produksi rata-rata ikan budidaya sekitar 6.450 ton per bulan atau 39,5\% dari seluruh produksi karamba jaring apung di Jawa Barat (Anonim, 2008). Jenis ikan yang dibudidayakan antara lain bawal air tawar (Collosoma macropomum), mas (Cyprinus carpio), nila (Oreochromis niloticus), (Pangasius. sp ) dan nilem (Osteochilus hasselti).

Perkembangan budidaya ikan di Waduk Cirata sangat pesat. Semula pada tahun 1988 jumlah KJA sekitar 3000 petak (Abery et al.,2005). Selanjutnya berdasarkan SK Gubernur Jawa Barat No. 41 Tahun 2002, jumlah KJA menjadi 12.000 petak, terbagi atas tiga zona, yaitu zona 1 di wilayah Kabupaten Bandung Barat sebanyak 1.896 petak, zona-2 di Kabupaten Purwakarta sebanyak 4.644 petak dan zona 3 di Kabupaten Cianjur sebanyak 5.460 petak. Tahun 2008, jumlah KJA mencapai 51.418 petak menempati badan air seluas 949 Ha. Kondisi ini sudah melewati daya dukung perairan (BPWC, 2008).

Melihat jumlah KJA di Waduk Cirata menyebabkan luasan waduk berkurang. Mulai tahun 2008 luasan waduk Cirata menurun menjadi 4.818 hektar (Radiarta \& Ardi, 2009., BPWC, 2008). Selain itu, kedalaman air waduk

Tabel 1. Lokasi pengamatan data lingkungan perairan

Table 1. Location of waters environment measurement mengalami perubahan dengan penumpukan pakan di dasar perairan. Penumpukan pakan yang terbuang dari KJA mencapai 325.712 ton dimana peningkatannya mencapai 5,6\% dibandingkan tahun 2007 (Rahmani et al., 2011).

Menurut Ardi (2013) degradasi lingkungan disertai fenomena alam seperti umbalan yang terjadi pada awal musim hujan menjadi pemicu kematian massal ikan budidaya. Kematian ikan secara massal dimulai tahun 1991 sebanyak 34,55 ton (Zafril., et al 2004). Pada 2004 kematian ikan sebanyak 550 ton terjadi di kampung Bayongbong, Kebon Cokelat, Calingcing, dan Babakan Garut. (Anonimus, 2004). Periode lima (5) tahun terakhir kematian ikan budidaya secara massal terjadi setiap tahun minimal frekuensi satu kali dalam satu tahun. Degradasi lingkungan perairan ditandai dengan peningkatan kesuburan perairan, sehingga mengakibatkan rendahnya oksigen terlarut dan ORP. Tujuan penelitian adalah untuk mendapatkan status lingkungan perairan dan kronologis kematian ikan massal serta mitigasinya di Waduk Cirata. Hasil penelitian di harapkan menjadi dasar dalam pengelolaan kegiatan budidaya ikan berkelanjutan di waduk Cirata dan sebagai prototipe di kawasan budidaya lainnya.

\section{BAHANDANMETODE Lokasi dan Waktu}

Pengamatan lingkungan perairan Waduk Cirata dilakukan pada 28-29 September 2017 (saat terjadi kematian ikan massal) meliputi Zona II ( wilayah Purwakarta), Zona I (wilayah Bandung Barat) dan Zona III (wilayah Cianjur) (Tabel 1 dan Gambar 1). Pengambilan sampel dan pengumpulan data lapangan dilakukan dengan metode observasi cepat insitu, analisa laboratorium, wawancara, dan studi pustaka.

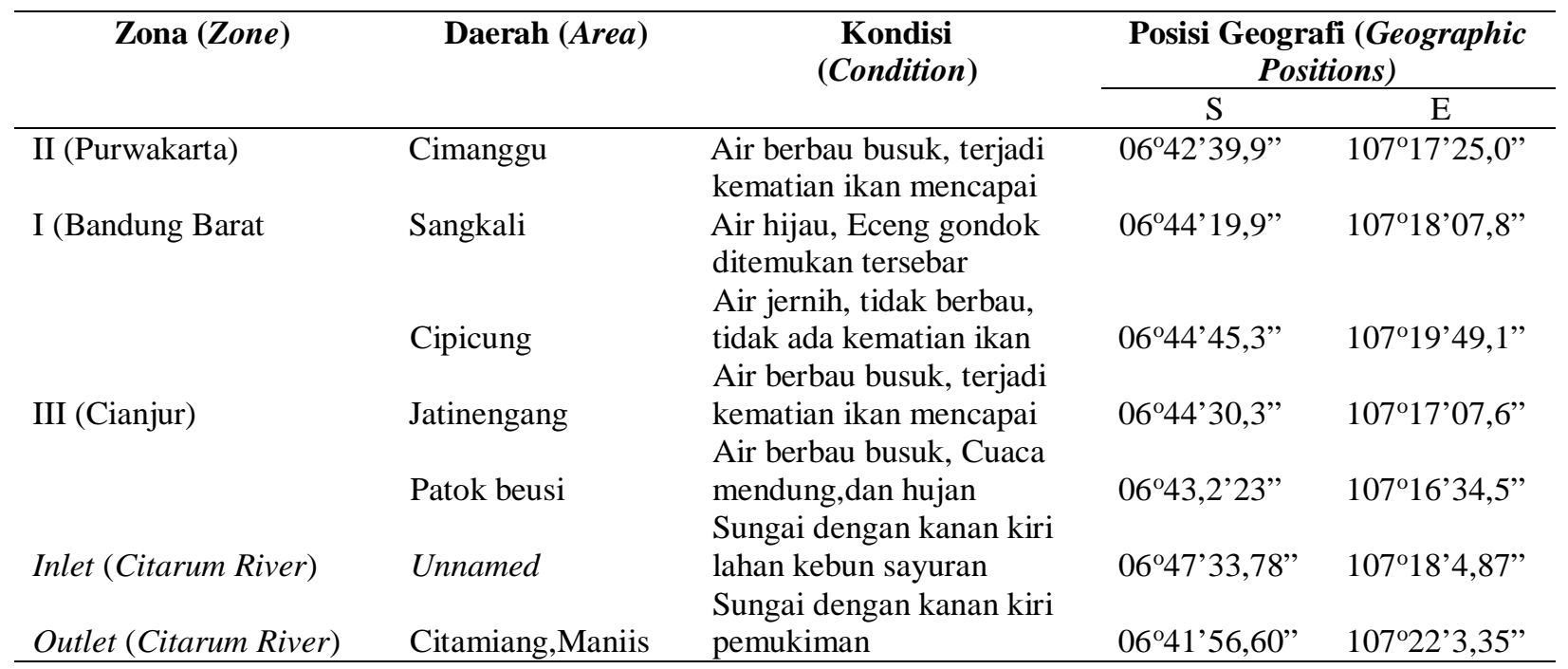




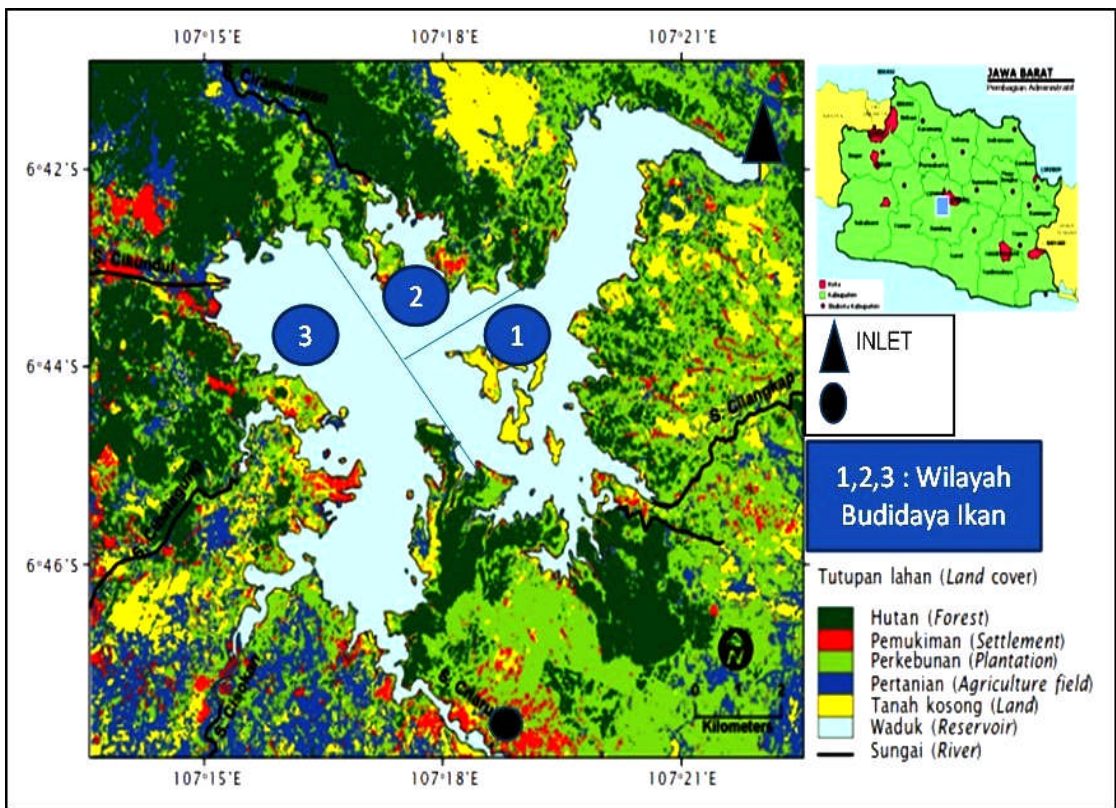

Gambar 1. Wilayah budidaya ikan keramba apung $(1,2,3)$ di Waduk Cirata.

Figure 1. Map showing the location of fish cage in Cirata reservoir.

Sumber: $\quad$ Radiarta \& Ardi ( 2009)

\section{Pengumpulan Data}

\section{Status degradasi lingkungan}

Pengambilan contoh air dilakukan di 5 lokasi yaitu: Cimanggu, Sangkali, Cipicung, Jatinengang dan Patok
Beusi (Tabel 1) pada kedalaman permukaan, tengah, dan dasar perairan. Beberapa parameter lingkungan perairan yang diukur meliputi fisika-kimiawi dan biologi perairan (Tabel 2).

Tabel 2. Parameter dan metode sampling kualitas perairan Waduk Cirata.

Table 2. Parameter and sampling method for water quality of Cirata Reservoir.

\begin{tabular}{|c|c|c|c|c|c|}
\hline $\begin{array}{l}\text { No } \\
(\mathrm{No})\end{array}$ & $\begin{array}{l}\text { Parameter } \\
\text { (Parameters) }\end{array}$ & $\begin{array}{l}\text { Satuan } \\
\text { (Unit) }\end{array}$ & $\begin{array}{l}\text { Alat } \\
\text { (Instrument) }\end{array}$ & $\begin{array}{l}\text { Metode Sampling } \\
\text { (Sampling } \\
\text { Method) }\end{array}$ & $\begin{array}{l}\text { Referensi } \\
\text { (References) }\end{array}$ \\
\hline 1. & $\begin{array}{l}\text { Fisika Air (Water ph } \\
\text { Suhu Air/Water } \\
\text { Temperature }\end{array}$ & $\begin{array}{l}\text { sically) } \\
{ }^{\circ} \mathrm{C}\end{array}$ & $\begin{array}{l}\text { Water quality checker, } \\
\text { insitu }\end{array}$ & Digital & Manualbook \\
\hline 2 & $\begin{array}{l}\text { Suhu Udara /Air } \\
\text { Temperature }\end{array}$ & ${ }^{\circ} \mathrm{C}$ & $\begin{array}{l}\text { Thermometer alkohol, } \\
\text { insitu }\end{array}$ & Manual & APHA. 2005. \\
\hline 3. & Kedalaman/Depth & $\mathrm{m}$ & Depth metre, insitu & Digital & APHA. 2005. \\
\hline 4. & $\begin{array}{l}\text { Kecerahan/Tanspar } \\
\text { ency }\end{array}$ & $\mathrm{m}$ & Secchi disk, insitu & Manual & APHA. 2005. \\
\hline 5. & $\begin{array}{l}\text { Kekeruhan/Turbidit } \\
y\end{array}$ & NTU & Turbidimeter, insitu & Turbidimetric & Manualbook \\
\hline 6. & $\begin{array}{l}\text { Total Padatan } \\
\text { Terlarut/Total } \\
\text { Dissolved Solids }\end{array}$ & $\mathrm{mg} / \mathrm{l}$ & $\begin{array}{l}\text { Water quality checker, } \\
\text { insitu }\end{array}$ & Digital & Manualbook \\
\hline 7. & $\begin{array}{l}\text { Total Suspensi } \\
\text { Terlarut/Total } \\
\text { Suspended Solids }\end{array}$ & $\mathrm{mg} / \mathrm{l}$ & $\begin{array}{l}\text { Gravimetric, } \\
\text { laboratorium }\end{array}$ & Gravimetri & APHA. 2005. \\
\hline 8. & $\begin{array}{l}\text { Warna air/water } \\
\text { color }\end{array}$ & kualitatif & Visual, insitu & Visual & APHA. 2005. \\
\hline 9. & $\begin{array}{l}\text { Konduktivitas/ } \\
\text { Conductivity } \\
\text { Kimiawi Air/Water C }\end{array}$ & $\begin{array}{l}\mathrm{mS} / \mathrm{cm} \\
\text { hemically }\end{array}$ & $\begin{array}{l}\text { Water quality checker, } \\
\text { insitu }\end{array}$ & Digital & Manualbook \\
\hline 10. & $\begin{array}{l}\text { Alkalinitas } \\
\text { /Alakalinity }\end{array}$ & $\mathrm{mg} / 1$ & Titrasi & Titrimetri & APHA. 2005. \\
\hline
\end{tabular}


Nastiti, A.S., et al/BAWAL. 10 (2) Agustus 2018: 99-109

\begin{tabular}{|c|c|c|c|c|c|}
\hline 11. & $\mathrm{pH}$ & unit & $\begin{array}{l}\text { Water quality checker, } \\
\text { insitu }\end{array}$ & Digital & Manualbook \\
\hline 12. & $\begin{array}{l}\text { Oxidation and } \\
\text { reduction } \\
\text { potential/ORP }\end{array}$ & $\%$ & $\begin{array}{l}\text { Water quality checker, } \\
\text { insitu }\end{array}$ & Digital & Manualbook \\
\hline 13. & $\begin{array}{l}\text { Dissolved } \\
\text { oxygen/DO }\end{array}$ & $\mathrm{mg} / \mathrm{l}$ & $\begin{array}{l}\text { Water quality checker, } \\
\text { insitu }\end{array}$ & Digital & Manualbook \\
\hline 14. & $\begin{array}{l}\text { Karbondioksida } \\
\text { bebas }(\mathrm{CO} 2) \\
\text { bebas/free } \mathrm{CO} 2\end{array}$ & $\mathrm{mg} / \mathrm{l}$ & Titrasi & Titrimetri & APHA. 2005. \\
\hline 15. & $\begin{array}{l}\text { Nitrogen-nitrate(N- } \\
\text { NO3 }\end{array}$ & $\mathrm{mg} / \mathrm{l}$ & Spektrofotometer & Brucine & SNI 06-2480-1991 \\
\hline 16. & $\begin{array}{l}\text { Nitrogen-nitrite (N- } \\
\mathrm{NO} 2 \text { ) }\end{array}$ & $\mathrm{mg} / \mathrm{l}$ & Spektrofotometer & $\begin{array}{l}\text { SNI 06-6989.9- } \\
2004\end{array}$ & SNI 06-6989.9-2004 \\
\hline 17. & $\begin{array}{l}\text { Nitrogen- } \\
\text { Ammonium(N- } \\
\text { NH4) }\end{array}$ & $\mathrm{mg} / \mathrm{l}$ & Spektrofotometer & Nessler & SNI 06-2479-1991 \\
\hline 18. & $\begin{array}{l}\text { Phosphor- } \\
\text { phosphate(P-PO4) }\end{array}$ & $\mathrm{mg} / \mathrm{l}$ & Spektrofotometer & $\begin{array}{l}\text { SNI 06-6989.31- } \\
2005\end{array}$ & SNI 06-6989.9-2004 \\
\hline $\begin{array}{l}19 . \\
20 .\end{array}$ & $\begin{array}{l}\text { Sulphat (S-SO4) } \\
\text { BOT/Total Organic } \\
\text { Material }\end{array}$ & $\begin{array}{l}\mathrm{mg} / \mathrm{l} \\
\mathrm{mg} / \mathrm{l}\end{array}$ & $\begin{array}{l}\text { Spektrofotometer } \\
\text { Titrasi }\end{array}$ & $\begin{array}{l}\text { Turbidimetry } \\
\text { Titrasi } \\
\text { permanganometri }\end{array}$ & SNIM-72-1990-03 \\
\hline 21. & $\begin{array}{l}\text { Biologi perairan/Wat } \\
\text { Data Dukung/Suppor } \\
\text { Kronologis } \\
\text { kematian ikan } \\
\text { massal/ } \\
\text { Chronologically of } \\
\text { mortality of mass } \\
\text { fish }\end{array}$ & $\begin{array}{l}\text { s Biologica } \\
\text { of data } \\
\text { kualitatif }\end{array}$ & $\begin{array}{l}\text { responden } \\
\text { Interview with fish } \\
\text { farmers, insitu }\end{array}$ & Wawancara, insitu & \\
\hline
\end{tabular}

\section{Kronologi Kematian Ikan Masal}

Pengambilan data dan informasi tentang kronologi kematian ikan dilakukan dengan metode wawancara terhadap 11 responden yang mewakili 3 zona budidaya. Beberapa pertanyaan yang diajukan meliputi: jumlah ikan yang mati, kenapa ikan mati, langkah yang dilakukan oleh pembudidaya sebelum dan pasca kematian ikan serta harapan dari pembudidaya ikan KJA.

\section{Mitigasi}

Langkah mitigasi dilakukan berdasarkan kondisi kualitas air terkini, jumlah KJA dibandingkan dengan daya dukung perairan, dan peristiwa alam yang secara eriodic terjadi (umbalan/upwelling)

\section{Analisa Data}

Data dianalisa secara deskriptif dalam bentuk tabel dan grafik. Dukungan data fisika-kimiawi air bagi biota perairan dibandingkan antar stasiun dan dengan Peraturan Pemerintah Lingkungan Hidup (PPLH) No.82 Tahun 2001, Boyd (1988 dan 1990), Wardoyo (1982), Horne \& Goldman (1994) dan Menkes No. 416/MENKES/PER/IX/1990 serta Scmittou (1991).
Nitrat dan fosfat merupakan fraksi senyawa nitrogen dan fosfor terkecil yang utama untuk aktivitas fotosintesis (Harris, 1978), juga sebagai indikator kesuburan perairan. Perairan oligotrofik kadar nitrat $0-1 \mathrm{mg} /$ perairan mesotrofik kadar nitrat 1-5 mg/perairan eutrofik kadar nitrat 5-50 mg/ 1(Vollenweider, 1968 dalam Wetzel, 1975 ). Perairan yang mengandung orthofosfat antara 0,003-0,010 mg/L merupakan perairan yang oligotrofik, 0,01-0,03 adalah mesotrofik dan 0,03-0,1 mg/Ladalah eutrofik (Vollenweider, 1968 dalam Wetzel, 1975). Kronologi kematian ikan massal berdasarkan wawancara dengan pembudidaya KJA dan pustaka yang mendukung di lokasi yang sama. Langkah mitigasi dianalisis berdasarkan kualitas air terkini, jumlah KJA dibandingkan dengan daya dukung serta disusunnya kalender periode umbalan/upwelling yang terjadi pada awal musim hujan stiap tahunnya.

\section{HASIL DAN BAHASAN \\ Hasil}

\section{Status Degradasi Lingkungan}

Suhu udara di Waduk Cirata pada siang hari udara cukup terik berkisar antara $30-32^{\circ} \mathrm{C}$ sedangkan pada sore hari $24{ }^{\circ} \mathrm{C}$ cuaca hujan. Hasil pengukuran parameter lingkungan perairan dapat dilihat pada Lampiran 1. 
Suhu air di permukaan berkisar antara $29,1-30,8^{\circ} \mathrm{C}$. Kedalaman $10 \mathrm{~m}$ berkisar antara $27,24-27,50{ }^{\circ} \mathrm{C}$ dan pada kedalaman $20 \mathrm{~m}$ berkisar antara $26-27,91^{\circ} \mathrm{C}$. Suhu air di Waduk Cirata menunjukkan kondisi suhu perairan yang umum dijumpai di perairan tropis.

Kedalaman air pada lokasi penelitian berkisar antara 20 - 41,2 m. Kedalaman KJA sekitar 8-9 m. Kecerahan air 0,8-0,9 m terdeteksi di zona II (Purwakarta) dan III (Cianjur) , sedangkan di zona I (Bandung Barat) kecerahan lebih tinggi yaitu berkisar antara 1,2-1,4 $\mathrm{m}$.

Turbiditas/kekeruhan di Waduk Cirata, di Zona I (Bandung Barat) turbiditas berkisara antara 3,8-32,6 NTU sesuai dengan profil kedalaman semakin bertambah kedalaman nilai turbiditas semakin meningkat. Nilai turbiditas berbeda dengan di zona III (Cianjur) berkisar antara 2,81- 11,2 NTU dan zona II (Purwakarta) berkisar antara 4,32-8,79 NTU, nilai turbiditas yang tinggi (keruh) dideteksi di kolom 0 dan $10 \mathrm{~m}$ sedangkan di kolom $20 \mathrm{~m}$ rendah. Zona II dan III jumlah kematian ikan massal lebih tinggi dibandingkan zona I.

TDS (Total Dissolved Solid) atau Total Padatan Terlarut di Waduk Cirata semakin meningkat dengan bertambahnya kedalaman. TDS di Waduk Cirata berkisar antara 0,046-0,172 mg/l. TSS (Total Suspended Solid) di waduk Cirata berkisar antara 4,17-70,67 mg/l. Berdasarkan kriteria TSS, diketahui bahwa TSS di waduk Cirata relatif kecil pengaruhnya terhadap kepentingan perikanan.
Alkalinitas di waduk Cirata berkisar antara 15,834- 31,668 $\mathrm{mg} / \mathrm{l}$. Konduktivitas air berkisar antara 0,132-0,258 mS/cm cenderung meningkat dengan bertambahnya kedalaman. Derajat keasaman $(\mathrm{pH})$ air cenderung netral yaitu berkisar antara 7,07 - 7,77. Kadar $\mathrm{CO} 2$ bebas sangat rendah di waduk Cirata berkisar antara 0-0,90.

Kadar nitrit di Waduk Cirata sangat rendah. Kadar amonia $\left(\mathrm{N}-\mathrm{NH}_{4}\right)$ di waduk Cirata berkisar antara sangat rendah - 1,785 (mg/l). Kadar Sulfat $\left(\mathrm{SO}_{4}\right)$ di perairan berkisar antara 10,86-37,38 mg/l. Kadar BOT (Total bahan organik) di perairan berkisar antara 5,37-11,38 mg/l.

Kadar nitrat di perairan berkisar antara 0,45-5,661 mg/ 1. Bila dilihat perkolom air seperti di Cimanggu, Patok Beusi, Sangkali dan Cipicung kadar nitrat cenderung meningkat di daerah permukaan, sedangkan secara normal kadar nitrat meningkat dengan bertambahnya kedalaman seperti yang terjadi di Jatinengang. Berdasarkan kriteria Vollenweider, 1968 dalam Wetzel, 1975 diketahui bahwa perairan Waduk Cirata termasuk dalam kategori eutrofik. Kadar fosfat di perairan berkisar antara 0,004-0,527 mg/l, semakin meningkat dengan bertambahnya kedalaman.

Konsentrasi oksigen terlarut di kolom air KJA mengalami penurunan kurang dari $3 \mathrm{mg} / \mathrm{l}$ (Gambar2). ORP (Oxidation Reduction Potentials) didefinisikan sebagai perubahan status oksidasi ion- ion metal dan senyawa nutrien (Goldman \& Horne, 1983). ORP di waduk Cirata, umumnya nilainya negative yaitu -49 sampai -244mv

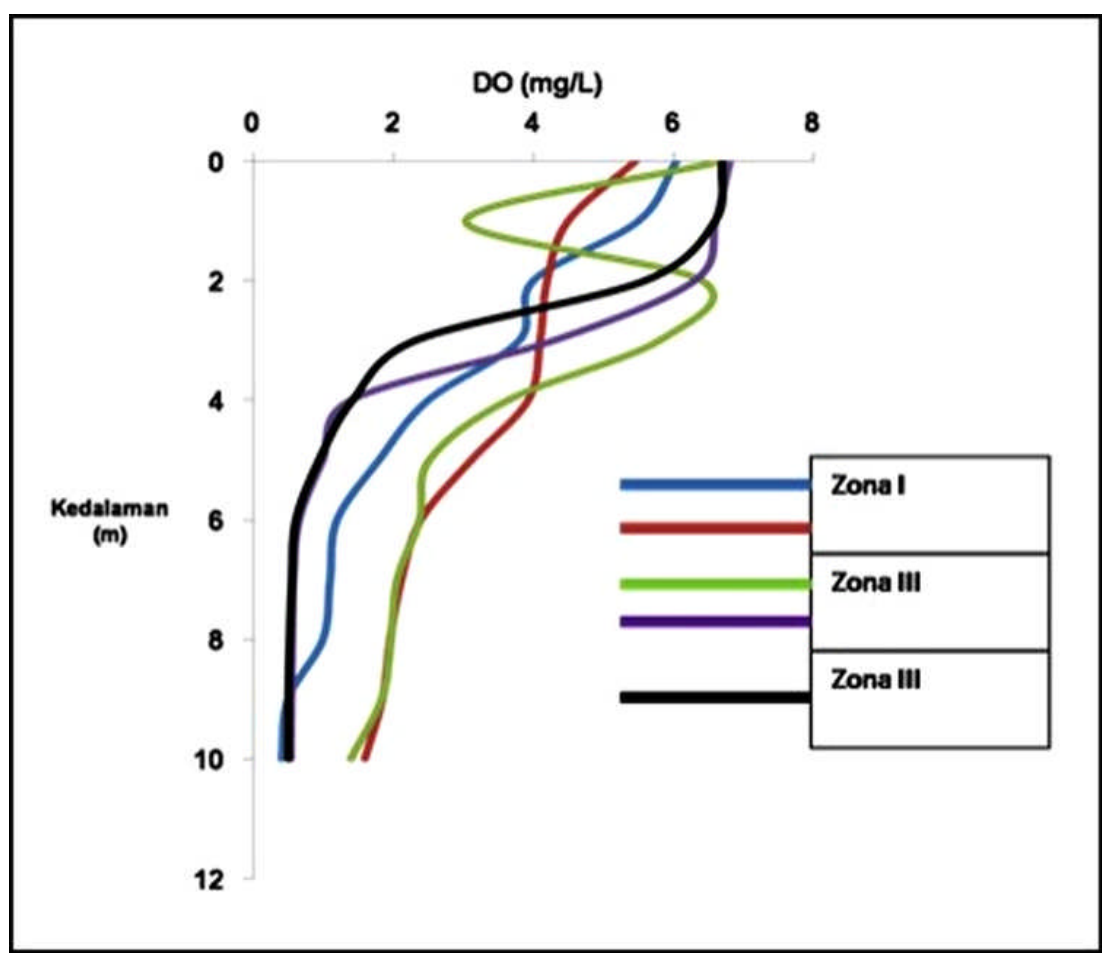

Gambar 2. Distribusi vertikal oksigen terlarut di waduk Cirata.

Figure 2. Vertical distribution of oxygen dissolved in Cirata reservoir. 


\section{Kronologi Kematian Ikan Massal}

Kematian massal ikan budidaya di Waduk Cirata pada akhir September 2017 yang tertinggi di Zona III dapat dilihat pada Tabel 3. Beberapa jenis ikan yang mati adalah: bawal, mas, dan nila.

Tabel 3. Kematian massal ikan budidaya dan kondisi cuacanya di Waduk Cirata

Table 3. Mass deaths of aquaculture fish and weather condition in Cirata Reservoir

\begin{tabular}{|c|c|c|c|c|c|}
\hline \multirow{2}{*}{$\begin{array}{l}\text { Tanggal } \\
\text { (Date) }\end{array}$} & \multirow{2}{*}{$\begin{array}{l}\text { Cuaca } \\
\text { (Weather) }\end{array}$} & \multicolumn{3}{|c|}{ Zona } & \multirow{2}{*}{$\begin{array}{l}\text { Sumber } \\
\text { (Source) }\end{array}$} \\
\hline & & $\begin{array}{c}\text { I } \\
\text { (Wilayah } \\
\text { Bandung } \\
\text { Barat) }\end{array}$ & $\begin{array}{c}\text { II } \\
\text { (Wilayah } \\
\text { Purwakarta) }\end{array}$ & $\begin{array}{c}\text { III } \\
\text { (Wilayah } \\
\text { Cianjur) }\end{array}$ & \\
\hline 24.09 .2017 & Mendung, Hujan & $\overline{\mathrm{V}}$ & $\mathrm{V}$ & $\mathrm{V}$ & Wawancara \\
\hline 25.09 .2017 & $\begin{array}{l}\text { Mendung, Hujan, } \\
\text { kematian ikan di } \\
\text { beberapa lokasi }\end{array}$ & & $\mathrm{v}$ & $\mathrm{v}$ & Wawancara \\
\hline 26.09 .2017 & $\begin{array}{l}\text { Mendung, Hujan } \\
\text { Tercium bau busuk }\end{array}$ & $\mathrm{v}$ & $\mathrm{v}$ & $\mathrm{v}$ & Wawancara \\
\hline 27.09.2017 & air keruh & $\mathrm{v}$ & $\mathrm{v}$ & $\mathrm{v}$ & Wawancara \\
\hline 28.09 .2017 & $\begin{array}{l}\text { Pukul } 01.00-05.00 \\
\text { kematian massal ikan } \\
\text { budidaya }\end{array}$ & 20 & 25 & 62 & $\begin{array}{r}\text { Pengamatan insitu, } \\
\text { Gandariksa, } 2017\end{array}$ \\
\hline 29.09 .2017 & $\begin{array}{l}\text { Pagi sampai siang } \\
\text { hari panas, sore hari } \\
\text { mendung hujan }\end{array}$ & $\mathrm{v}$ & $\mathrm{v}$ & $\mathrm{v}$ & Pengamatan insitu \\
\hline
\end{tabular}

\section{Mitigasi}

Hasil wawancara diperoleh informasi sebagai berikut ; mitigasi yang dilakukan oleh beberapa pembudidaya ikan adalah memberikan aerasi, menghentikan pemberian pakan, melakukan pemanenan. Perlakuan setelah terjadi kematian ikan, adalah menjual ikan kepada pengumpul, mengawetkan ikan dengan es atau garam, atau membuang ikan ke perairan di luar KJA. Kendala yang dihadapi para pembudidaya diantaranya adalah: terbatasnya jumlah penampung, turunnya harga ikan, sarana pengawetan ikan (terbatasnya ketersediaan es), minimnya pengetahuan tentang penanganan pasca kematian (biasanya dibuang di luar KJA). Harapan bagi para pembudidaya ikan adanya lembaga koperasi untuk mendukung pemasaran dan kestabilan harga ikan (saat kematian massal harga ikan sangat rendah), tersedianya sarana pengawetan ikan (pabrik es dan cold storage), pembentukan kelompok (POKMASWAS), peningkatan pengetahuan tentang penanganan ikan pasca kematian, dan peningkatan pengetahuan cara budidaya ikan yang baik

\section{Bahasan}

\section{Status Degradasi Lingkungan}

Perairan Waduk Cirata telah mengalami degradasi yang ditandai dengan rendahnya kadar oksigen terlarut yang kurang dari $3 \mathrm{mg} / \mathrm{l}$. Oksigen terlarut penting dalam proses respirasi biota /ikan, dan rendahnya ORP, perairan yang sehat memiliki nilai ORP 300-500mV. Rendahnya kadar oksigen terlarut di bawah permukaan di semua zona (Gambar 3) karena tingginya kesuburan perairan (eutrofik) dampak dari akumulasi sisa pakan komersiil yang mengandung unsur $\mathrm{N}$ (nitrat) dan $\mathrm{P}$ (orthophosphat) (Lampiran 1). Akumulasi pakan komersiil meningkat dengan meningkatnya jumlah petak KJA semakin berkembang dari tahun 1988 kurang lebih 3000 petak, tahun 2002 sebanyak 12.000 petak, dan menurut catatan sudah mencapai 31.000 unit yang seharusnya hanya 7.037 unit (Kartamihardja \& Krismono, 2016). Beberapa jenis pakan yang digunakan oleh pembudidaya di Waduk Cirata ( Tabel 4). Unsur P (Phosphor), nitrogen dari protein dalam pakan komersiil dan $\mathrm{P}$ dapat menyebabkan eutrofikasi. Eutrofikasi ini sebagai pemicu terjadinya Alga blooming sehingga oksigen terlarut turun (Vollenweider, 1968 vide Wetzel, 1975).

Menurut Mc Donald et al. (1996) dalam Simarmata (2007), bahwa 30\% dari jumlah pakan yang di berikan tertinggal sebagai pakan yang tidak di konsumsi dan 25 $30 \%$ dari pakan yang di konsumsi akan diekskresikan. Hal ini menunjukkan jumlah yang cukup besar dari sisa pakan tersebut masuk ke perairan yang menjadi materi pencemar.

Berikut ini perhitungan estimasi jumlah pakan yang terakumulasi di dasar waduk Cirata ( Tabel 5): 
Tabel 4. Komposisi pakan di Waduk Cirata

Table 4. Composition of feed in Cirata Reservoir

\begin{tabular}{cccccc}
\hline Komposisi/ & \multicolumn{5}{c}{ Jenis Pakan (feed composition) } \\
\cline { 2 - 6 } Composition & Satuan/unit & ARTHA & FI-Diamond & GLOBAL & FI-Prima \\
\hline Kadar air (water) & $\%$ & 12 & 12 & 12 & 12 \\
Protein kasar (crude protein) & $\%$ & 25 & 24 & 26 & $24-26$ \\
Lemak kasar (crude fat) & $\%$ & 5 & 6 & 5 & $5-7$ \\
Serat kasar (fiber crude) & $\%$ & 6 & 7 & 6 & 7 \\
Abu (ash) & $\%$ & 10 & 12 & 13 & 12 \\
Calcium & $\%$ & 2,5 & 1,5 & & 12 \\
Phosphor & $\%$ & 1,5 & 1 & $0,7-1,5$ \\
\hline
\end{tabular}

Tabel 5. Estimasi jumlah pakan yang terakumulasi di dasar waduk Cirata selama satu tahun

Table 5. Total estimation of feed accumulated at the base of the Cirata reservoir for one year

\begin{tabular}{|c|c|c|}
\hline No & Uraian/(Description) & Perhitungan/( Calculation) \\
\hline 1 & Jumlah unit KJA (Total of Unit Floating Net Cage) & 31.000 unit atau 124.000 petak \\
\hline 2. & KJA yang tidak aktif (Floating Net Cage Non Aktive): $20 \%$ & 24.800 petak \\
\hline 3 & KJA yang aktif ( Floating Net Cages Aktive) & $124.000-24.800=99.200$ petak \\
\hline 4 & $\begin{array}{l}\text { Jumlah pakan komersil per plot selama } 3 \text { bulan( The amount of } \\
\text { commercial feed per plot during } \\
\text { for } 3 \text { months.) }\end{array}$ & 2 ton \\
\hline 5 & $\begin{array}{l}\text { Total pakan komersil } \\
\text { ( Total of commercial feed) }\end{array}$ & $99.200 \times 2$ ton $=198.400$ ton \\
\hline 6 & $\begin{array}{l}\text { Total pakan dalam } 1 \text { tahun (Total of commercial feed on one } \\
\text { year) }\end{array}$ & $198.400 \times 4$ kali $*)=793.600$ ton \\
\hline \multirow[t]{4}{*}{7} & Komposisi pakan komersiil (Composition of commercial feed) & \\
\hline & Protein $(N): 24-26 \%$ & $93.803,52-101.620,48$ ton \\
\hline & $: 1,5-2,5 \%$ & $5.862,72-9.771,2$ ton \\
\hline & $: 1-1,5 \%$ & $3.908,48-5.862,72$ ton \\
\hline 8 & $30 \%$ pakan yang terbuang ( $30 \%$ wasted feed $)$ & 238.080 ton \\
\hline 9. & $25-30 \%$ diekresikan (25-30\% excretion) & 152.768 ton \\
\hline \multicolumn{3}{|c|}{ Jadi total pakan yang terbuang (total wasted feed) } \\
\hline \multicolumn{3}{|c|}{238.080 ton +152.768 ton $=390.848$ ton.} \\
\hline \multicolumn{3}{|c|}{ *) dalam setahun dilakukan penebaran 4 kali } \\
\hline
\end{tabular}

Menurut Jubaedah et al. (2014), nilai indeks pencemaran berdasarkan parameter kualitas air di Waduk Cirata yaitu 14,431 maka dikategorikan tercemar berat. Berdasarkan unsur $\mathrm{N}$ dan $\mathrm{P}$ termasuk perairan dalam kategori eutrofik, dilihat dari konsentrasi nitrat dan orthophosphat. Indikator eutrofik di Waduk Cirata adalah perairan yang berwarna hijau keruh dari kelimpahan fitoplankton. Menurut hasil penelitian Zahidah dan Nurruhwati (2005), kelimpahan fitoplankton di Waduk Cirata pada tahun 1997 berkisar antara 44.800-62.280 sel $\mathrm{m}^{3}$ pada siang hari yang didominasi oleh kelas Cyanophyceae. Selanjutnya menurut hasil penelitian Purnamaningtyas \& Tjahjo (2010), pada tahun 2009 di Waduk Cirata didominasi oleh kelas Cyanophyceae dengan kelimpahan $730.446 \mathrm{sel} / \mathrm{L}$. Menurut Nurcahya dan Nugraha (2013) kelimpahan fitoplankton di Waduk Cirata didominasi oleh kelas Cyanophyceae $\mathrm{Hal}$ ini memperkuat dugaan bahwa Waduk Cirata telah menjadi perairan eutrof.

Perairan Waduk Cirata dengan tingkat pencemaran yang berat dan tingkat kesuburan yang eutrofik berpengaruh terhadap profil beberapa parameter diantaranya adalah stratifikasi oksigen terlarut dan rendahnya nilai ORP (Oxygen Reduction Potential). Distribusi vertikal DO dipermukaan perairan terdeteksi di atas $4 \mathrm{mg} / \mathrm{l}$, dengan bertambahnya kedalaman perairan DO semakin menurun (Gambar 3) yang membahayakan bagi ikan yang terkurung dalam KJA. Kedalaman KJA mencapai 8-9 m, konsentrasi oksigen mengalami penurunan kurang dari $3 \mathrm{mg} / \mathrm{l}$ dalam grafik terdeteksi kurang dari $2 \mathrm{mg} / \mathrm{l} \mathrm{sampai}$ kurang dari $1 \mathrm{mg} / \mathrm{l}$, kondisi sesuai dengan hasil penelitian Effendi et al. (2012). Pengukuran ini dilakukan setelah kematian massal ikan pada 29 September 2017. Pada Gambar 3, menunjukkan bahwa umumnya kondisi kualitas air setelah kedalaman $2 \mathrm{~m}$ kadar oksigen terlarut terus turun. Kondisi ini didukung hasil penelitian Santoso et al.,(2012) analisa konsentrasi oksigen terlarut di Waduk Cirata yang dibagi menjadi 3 zona yaitu zona Riverine (Sungai Citarum), Lacustrine (Wilayah Budidaya Ikan), dan Genangan Utama menunjukkan pola yang sama, yaitu mengalami penurunan yang drastis hingga pada kedalaman $5 \mathrm{~m}$. Kestabilan oksigen terlarut di zona Genangan Utama 
dan zona Lakustrin memiliki kestabilan oksigen terlarut yang rendah sementara zona Riverin sedikit lebih diuntungkan karena posisinya yang dekat muara sungai yang memungkinkan massa badan air pada zona tersebut berpotensi sering terbilas

Nilai ORP di kolom perairan menurun kurang dari 100 $\mathrm{mV}$, sulfat direduksi menjadi hidrogen sulfida $\left(\mathrm{H}_{2} \mathrm{~S}\right)$ maka kolom dalam perairan kaya akan $\mathrm{H}_{2} \mathrm{~S}$ (Wetzel, 2001). Hasil deteksi ORP di Waduk Cirata dengan nilai negatif mengindikasikan tingginya konsentrasi $\mathrm{H}_{2} \mathrm{~S}$ di seluruh kedalaman di lima lokasi pengukuran (Cimanggu, Jatinengang, Patokbeusi, Sangkali dan Cipicung) (Lampiran 1). perairan tercemar, artinya bahwa perairan tidak mampu untuk mendekomposisi limbah pakan. Konsentrasi H2S ini merupakan gas racun yang menyebabkan kematian ikan massal. Perairan yang baik dengan nilai ORP 300-500mV, artinya bahwa perairan masih memiliki kemampuan self purification atau mampu mendekomposisi limbah. Perairan dengan ORP positif adalah perairan dengan $\mathrm{pH}$ netral, suhu air $25^{\circ} \mathrm{C}$ dan kaya oksigen dan sebaliknya (Horne dan Goldman, 1994). Gasgas racun seperti $\mathrm{NH}_{3}, \mathrm{H}_{2} \mathrm{~S}, \mathrm{PH}_{3}$. (Mantiq, 2016 \& Nurwahid, 2013). Dalam kondisi perairan sangat minim kadar oksigen terlarut maka amonium diperairan akan bersenyawa dengan sulfat menjadi amonium sulfat selanjutnya bereaksi dengan kalium hidroksida akan menghasilkan gas amonia yang beracun bagi ikan

\section{Kronologi Kematian Ikan Massal}

Kematian ikan massal budidaya di Waduk Cirata dipicu oleh fenomena alam umbalan. Indikator fenomena "umbalan" di Waduk Cirata tercium bau busuk yang menyengat dari gas-gas racun. Bau busuk menyengat dari gas-gas racun berasal dari dekomposisi akumulasi pakan di dasar perairan pada suasana an aerob (rendah atau tidak ada oksigen) yang sampai ke permukaan karena peristiwa umbalan. Fenomena umbalan atau upwelling yang sering terjadi di Waduk Cirata sebagai berikut; adalah sebuah fenomena di mana air permukaan yang lebih dingin dengan massa jenis lebih besar akan turun di kolom dasar perairan selanjutnya dengan dorongan angin massa air di kolom dasar perairan bergerak ke permukaan dengan kualitas lingkungan perairan yang jelek yang menyebabkan kematian ikan. Umbalan diawali dengan turunnya suhu air permukaan, pendinginan suhu air permukaan karena cuaca mendung dan hujan selama 4 (empat) hari berturut-turut. Suhu air yang dingin secara fisik akan turun sampai pada kolom air dengan suhu yang sama, kemudian dengan kekuatan angin dan arus dari sungai akan naik ke kolom permukaan dengan kualitas air yang tercemar (gas-gas racun dan oksigen rendah) sehingga ikan dalam KJA akan stress. Umbalan yang terjadi di Waduk Cirata, terdeteksi dari turbiditas dan nitrat yang masih tinggi di kolom 0-10 m.
Tingginya jumlah kematian ikan massal di Waduk Cirata karena cara budidaya ikan yang baik (CBIB) tidak dipatuhi diantaranya adalah padat tebar yang tinggi. Ukuran petak $(7 \times 7 \times 8-9) \mathrm{m}^{3}$ padat tebar bawal berkisar $13.000-15.000$ ekor dan membutuhkan pakan 3 ton dengan pemeliharaan selama 45 hari, sedangkan untuk ikan mas ukuran petak (7x7x 8-9) $\mathrm{m}^{3}$ padat tebar $1-2 \mathrm{kwintal}$ benih dengan jumlah pakan 3 ton dengan lama pemeliharaan 6 bulan. Sebagai perbandingan, di Waduk Ir. H. Djuanda Jatiluhur, dengan kualitas lingkungan perairan lebih baik dibandingkan dengan di Waduk Cirata, kegiatan budidaya ikan padat tebar ikan mas sama dengan di Waduk Cirata. Artinya bahwa padat tebar ikan budidaya di Waduk Cirata perlu dikurangi disesuaikan dengan kondisi kualitas airnya. Menurut Schmittou (1991) kekurangan oksigen terlarut dalam jangka waktu lebih dari 8 jam sebagai indikasi degradasi lingkungan, menjadi penyebab ikan lemas yang berkepanjangan yang akhirnya mati.

\section{Mitigasi}

Langkah mitigasi yang penting dilakukan adalah pemulihan habitat sumber daya ikan. Kegiatan pemulihan yang segera dilakukan adalah perbaikan kualitas lingkungan perairan di Waduk Cirata diantaranya adalah dengan menurunkan padat tebar ikan budidaya di Waduk Cirata sekitar 50\% dari yang sekarang, pengurangan jumlah KJA sesuai daya dukung perairan terkini, dan penghentian sementara kegiatan budidaya ikan. Hal dilakukan dalam rangka memberikan kesempatan agar alam/perairan melakukan pemulihan. Perilaku alam yang terjadi secara periodik yaitu umbalan/upwelling maka perlu menyusun kalender terjadi umbalan yang dipubilkasikan oleh penyuluh kepada masyarakat pembudidaya agar mempersiapkan dampak dari umbalan/upwelling yaitu kematian ikan massal. Satu hal lagi yang bisa dilakukan namun dengan biaya yang mahal adalah pengerukan pakan yang terakumulasi di dasar perairan.

\section{KESIMPULAN}

Lingkungan perairan Waduk Cirata dengan kadar oksigen terlarut (dibawah $4 \mathrm{mg} / \mathrm{l}$ ) dan ORP (negatif) rendah, mengindikasikan bahwa perairan mengalami degradasi yang menyebabkan kematian massal ikan budidaya.

Rekomendasi untuk menjaga lingkungan perairan di waduk Cirata meliputi; 1) Mengurangi padat tebar sekitar $50 \%$ dari yang sekarang oleh pembudidaya dengan penyuluh perikanan., 2) Memperbaiki pola budidaya intensif dengan CBIB (Cara Budidaya Ikan yang Baik), termasuk penghitungan kembali daya dukung perairan oleh Dinas Perikanan Kelautan Jawa Barat yang bekerjasama dengan Badan Riset Sumber Daya Manusia Kelautan Perikanan-KKP., 3) Monitoring kualitas air sebagai dasar peringatan dini (early warning system) oleh 
Badan Riset Sumber Daya Manusia Kelautan PerikananKKP bekerjasama dengan BPWC (Balai Pengelola Waduk Cirata).,4) Membentuk koperasi sebagai lembaga yang mengkoordinir kegiataan budidaya ikan dalam hal stabilitas harga, penyedia benih dan pakan; 5) Membangun jaringan antara pembudidaya dan pemerintah., Pembentukan kelompok (POKMASWAS) untuk peningkatan pengetahuan pembudidaya seperti penanganan masalah sebelum, saat dan sesudah kematian ikan massal, termasuk penyelenggaraan sarana pabrik es dan cold storage .

\section{PERSANTUNAN}

Analisis Degradasi Lingkungan Perairan Dan Keterkaitannya Dengan Kematian Massal Ikan Budidaya Di Waduk Cirata, Jawa Barat, Indonesia merupakan kegiatan penelitian "Quick Respons Pusat Riset Perikanan" dengan sumber dana APBN tahun anggaran 2017. Penulis mengucapkan terimakasih kepada Kepala Pusat Riset Perikanan yang telah memberi ijin untuk menggunakan data untuk karya tulis ilmiah.

\section{DAFTARPUSTAKA}

Abery, N.W., Sukadi, F., Budhiman, A.A., Kartamihardja, E.S., Koeshendrajana, S., Buddhiman., \& De Silva, S.S. (2005). Fisheries and cage culture of three reservoirs in West Java, Indonesia: A case study of ambitious development and Resulting interactions. Fisheries Management and Ecology, 12, 315-330

Anonim. (2008). Waduk Cirata. Pembawa berkah yang dipenuhi sampah.

http.www.akuinginhijau.wordpress.com.

Anonim. (2004). 550 Ton ikan di Cirata mati mendadak, petani rugi miliaran. https://news.detik.com/berita/d250605/550-ton-ikan-di-cirata-mati-mendadakpetani-rugi-miliaran.

APHA (American Public Health Association). (2005). Standard Methods for Examination of Water and Wastewater . (20 th ed). Washington, DC. Hal. 10(2), 10-18

Ardi, I. (2013). Budidaya ikan sistem keramba jaring apung guna menjaga keberlanjutan lingkungan perairan Waduk Cirata. Media Akuakultur. 8(1), 23-29.

Boyd, C. E. (1988). Water quality management for pond fish culture (p. 359). Auburn University.

Boyd, C. E. (1990). Water quality in ponds for aquaculture (p. 482). Auburn University.
BPWC (Balai Pengelola Waduk Cirata). (2008). Laporan kegiatan inventarisasi sensus kolam jaring apung. Balai Pengelola Waduk Cirata. Bandung.

Effendi, H., Adiwilaga, E.M., \& Sinuhaji, A. (2012). Pengaruh pencampuran air terhadap oksigen terlarut di sekitar Karamba Jaring Apung, Waduk Cirata, Purwakarta, Jawa Barat. Ecolab, 6 1, 51-60.

Gandariksa, R. (2017). Laporan data sementara terkait isu kematian ikan di KJA Waduk Cirata Zona III Kab. Cianjur Jawa Barat (p. 10). BPPPU Kabupaten Cianjur.

Goldman, C. R., \& Horne, A. J. (1983). Limnology. McGraw -Hill Inc. United State of America. xvi + 464.

Horne, A.J., \& Goldman, C.R. (1994). Limnology (p. 576). Second Edition. McGraw-Hill Inc. New York.

Jubaedah, I., Sudinno, D., \& Anas, P. (2014). Budidaya keramba jaring apung di Waduk Cirata,Kabupaten Cianjur Provinsi Jawa Barat. Jurnal Penyuluhan Perikanan, 8(1), 9-22.

Kartamihardja, E.S., \& Krismono. (2016). Fenomena, penyebab dan pengendalian kematian ikan serta pengembangan budidaya ikan dalam keramba jaring apung berkelanjutan di perairan waduk dan danau. Diambil dari bahan Policy Brief. 14 hal.

Nurcahya, Y., \& Nugraha, Y. (2013). Komposisi dan kelimpahan fitoplankton di Waduk Cirata, Jawa Barat. Buletin Teknisi Litkayasa, 11(1), 37-43.

Nurulwahid. (2013). Mengidentifikasi parameter air secara fisika dan kimia. https:// nurulwahidadotme.wordpress.com.

Pengelolaan Kualitas Air dan Pengendalian Pencemaran Air (Peraturan Pemerintah Nomor 82, 2001).

Purnamanintyas, S. E., \& Tjahjo, D. W. H. (2010). Hubungan kelimpahan fitoplankton dengan kualitas air di Waduk Cirata, Jawa Barat. Prosiding Seminar Nasional Tahunan Hasil Penelitian Perikanan dan Kelautan Manajemen Sumber Daya Pesisir, VII (2), 16.

Radiarta, I. N., \&. Ardi, I. (2009). Pemetaan distribusi keramba jaring apung ikan air tawar di Waduk Cirata, Jawa Barat dengan multi temporal data. J. Ris. Akuakultur, 4(3), 439-446.

Rahmani, U., Syaukat. Y. Fauzi, A., \& Hidayat, A. (2011). Internalisasi biaya lingkungan pada budidaya ikan 
karamba jaring apung di Waduk Cirata. Indonesian Journal of Agricultural Economics, 2 (2), 157-168.

Santoso, A.D., Susanto, J.P., \& Komarawidjaya, W. (2012). Edisi khusus hari lingkungan hidup. Jurnal Teknik Lingkungan, 139-145.

Syarat-syarat dan Pengawasan Kualitas Air (Peraturan Pemerintah Menkes No.416/Men.Kes/Per/IX/1990).

Schmittou, H.R. (1991). Budidaya Karamba: Suatu Metoda Produksi Ikan di Indonesia (p. 126). FRDP. Puslitbang Perikanan. Jakarta.

Simarmata, A.R. ( 2007). Kajian keterkaitan antara cadangan oksigen dengan beban masukan bahan organik di Waduk Ir. H. Djuanda Purwakarta, Jawa Barat. Tesis. Bogor: Institut Pertanian Bogor.

Soemarwoto, O., Roem, C.M., Herawati, T., \& Costa-Pierce, B.A. (1990). Water quality suitability of Saguling and Cirata reservoirs for development of floating net cage aquaculture. In: Costa-Pierce, B.A, Soemarwoto, O (eds) Reservoir Fisheries and Aquaculture
Development for Resettlement in Indonesia Manila, Philippines: ICLARM, Technical Report 23, 18111.

Soeprapto, H. (2009) Manfaat cahaya bagi algae khususnya Chlorophyta. Pena Aquatika, 1(1) 14-18.

Wardoyo, S.T.H. (1982). Water analysis manual tropical aquatic biology program (p. 81). Biotrop, SEAMEO. Bogor.

Wetzel, R.G. (2001). Limnology lake and river ecosystem (p. 1006). 3th ed. Academic Press., New York.

Wetzel, R.G. (1975). Limnology (p. 743). Philadelphia: W.B. Sounders Company.

Zahidah \& Nurruhwati, I. (2005). Komunitas fitoplankton di zone keramba jaring apung (KJA) di Waduk Cirata. Pemanfaatan dan Pengelolaan Perairan Umum Secara Terpadu Bagi Generasi Sekarang dan Mendatang. Pusat Riset Perikanan Tangkap. Prosiding Forum Perairan Umum Indonesia. 1, 257-260. 


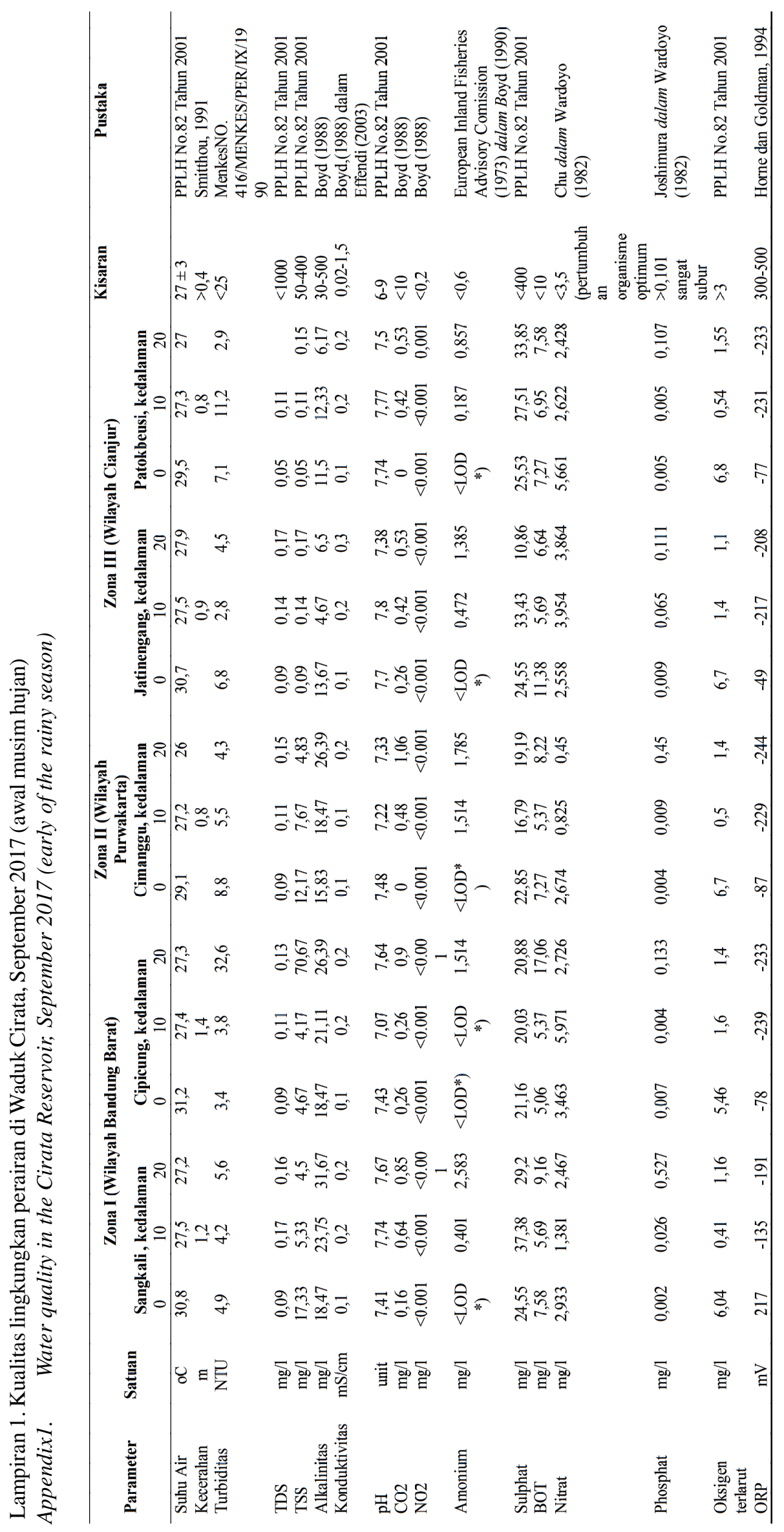

